\title{
シルバーピア住宅における団らん室の有効活用に関する研究 A STUDY ON USE OF SILVER-PEER'S COMMUNITY ROOM
}

\author{
大塚順子*, 定行まり子** \\ Junko OHTSUKA and Mariko SADAYUKI
}

\begin{abstract}
This study aims investigate how to use the silver-peer's community room as base of neighboring area. We analyzed about the silver-peer's community room used well by three researches. The result of the analysis is as follows,

(1) The community room functions as an important place.(2)The community room is used with the resident of the silver-peer and the neighboring area people without constraint. Because Wardens or Life support advisers(LSA) stay the community room every time when there open. (3)Most of the community room's events ware planed by Warden and LSA. (4)It is important that the silver-peer resident use the community room with the neighboring area people than only silver-peer resident.(5)It is often that the elderly uses the community room in a small group. Therefore it is not important that the space is large. It is important that there is always warden or LSA and there is easily usable.
\end{abstract}

Keywords : The Elderly, Silver-peer, Community room, The Neighboring relations 高齢者, シルバーピア住宅, 団らん室, 地域交流

\section{1. 研究の背景と目的}

加速する高齢化に伴い、身体機能の虚弱な後期高齢者や認知症の 増加が大きな問題として取り上げられ、安全な住まいと生活支援の 確保が指摘されている。こうした背景を受けて、建築行政、福祉行 政の各分野から多くの施策が展開され、両者の連携によって 1987 年に始まったシルバーハウジング・プロジェクトやシルバーピア事 業は、高齢者住宅のさきがけとして注目されてきた。シルバーハウ ジングは、阪神淡路大震災による災害復興住宅の一つとして注目さ れ、住戸配置や平面計画に関する研究 ${ }^{1)}{ }^{2)}$ 、入居高齢者の近隣交流 と共用空間の利用に関する研究 $\left.{ }^{3}\right)^{4)}$ などの事例分析が多数されて きた。しかし、最近では、高齢者優良賃貸住宅などの新しい高齢者 住宅が着目され、公的高齢者住宅の今後や既存ストックとしての活 用に焦点を当てた研究はほとんど見られない。シルバーハウジング は、837 住宅 22561 戸(平成 20 年 3 月現在)が供給され、最も供給 数が多い東京都では約 $1 / 4$ を占めている。区市等の財政難などによ り新規供給は減少に転じているが、単身高齢者が多い都市部の特性 を考慮した独自の取り組みである東京都シルバーピア事業では、既 に 486 住宅 9943 戸（平成 19 年 3 月現在）が供給されている。 本研究は、シルバーピア(以下、ピア)のストックとしての価值に 注目し、地域財産としての今後の有効活用を検討することを目的と した研究の一部である。前稿（2009.1）5）では、東京都内の既存ピ アの住棟形態を分析し、多くのピアに共用空間として団らん室注 1) が設置されているが、その利用頻度は低いことを明らかにした。し
かし、団らん室は、接地性のある配置が多く、周辺住民からの関心 が高いことや複合住棟では利用が多く、生活協力員注 2)の管理方法 が利用頻度に影響しているなど注目すべき点を把握できた。介護保 険制度の導入以後、地域社会全体で高齢者の生活を支える方向性が 明確に示されている。そこで、本稿では、利用頻度の高い団らん室 に焦点をあて、企画設定および活動の継続性について関連する人と 空間の使い方を中心に考察する。これにより、既存ピアの団らん室 を高齢者の生活支援に有効な地域拠点の場として活用していくため の知見を得ることを目的とする。

\section{2. 研究の方法}

本研究では、(1)生活協力員に対するヒアリング調査、(2)団らん室 の参与観察調查、(3)団らん室利用者に対するアンケート調查の 3 つ の調查分析を行った。これらを通して、団らん室の利用実体を明ら かにし、利用に関わる経緯等を踏まえて考察をまとめる。調查概要 は、表 1 の通りである。(1)(2)ついては、事業計画書および生活協 力員調查結果注 3$)$ 、区市町村担当者一の聴取注4) に基づいて、建物に 特徵があるピア、団らん室の利用頻度が高いピアを観察対象として 選定した。さらに、10 ピアについては、利用実態に関する参与観察 調査と生活協力員への聞き取り調査を実施した。(3)はアンケート形 式を前提とし、一部、調查員が聞き取りに基づいて記入した。

\section{3. 調査対象の概要}

\footnotetext{
本論文の一部は, 日本建築学会学術講演梗概集に発表した(参考文献 6 )。

*日本女子大学 学術研究員・博士 (学術)

** 日本女子大学家政学部住居学科 教授·工博
}

Research Fellow, Japan Women's University, Ph. D.

Prof., Dept. of Housing and Architecture, Japan Women's University, Dr. Eng. 
調查対象として選定した 10 ピアの概要を表 2 に示す。そのうち、 団らん室についての概要を表 3 に示す。

\section{（1）シルバーピアの住棟の高さと構成}

調查対象ピアの住棟高さは、3〜 5 階の中層棟が 5 ピア、残り 5 ピアはそれ以上の高層棟で構成されている。ピアの住棟構成は、ピ ア住戸を含む 1 棟で構成された 1 棟型が 6 ピアで、シルバーピア以 外の住棟と複数が建設されている構成の団地型が 4 棟である。ピア 住棟の形態は、一般住宅、施設等との複合型が多いが、ピア住戸の みで構成された単独型は 2 ピアのみである。

\section{(2) 入居者状況}

入居者平均年齢は、 $72 \sim 82$ 歳で、最年少が 65 歳、最高齢は 94 歳である。身体状況では、要介護状態の者が 4 人以上いるピアが多 いことから入居者の高齢化は著しく、身体状況も低下している者が 多いことが確認できた。

\section{（3）生活協力員状況}

生活協力員状況は、ピアごとに異なる。ワーデン・L S A の違い 注5) のほかに、専用住戸がありピア入居者を常時見守る常駐型か執 務室しかない派遣型か、などの勤務状況、資格の有無などに違いが みられる。常駐型は 8 ピア、派遣型は 2 ピアのみである。 1 人勤務 で、開設当初から継続している人が多い。派遣型の (6) C K 住宅は 4 人の複数体制で、勤務時間も 9:00〜 13:00 までと短い。年齢は 36 歳〜 67 歳と幅広く、女性がほとんどである。L S A は医療・福祉の 専門資格所有者が多いがワーデンは無資格者が多い。

\section{表 1 調查概要}

\begin{tabular}{|c|c|c|c|}
\hline & $\begin{array}{ll}\text { 調查(1) } & \text { 生活協力員 } \\
& \text { ヒアリング調查 } \\
\end{array}$ & $\begin{array}{l}\text { 調查(2) 団らん室 } \\
\text { 参与観察調查 }\end{array}$ & $\begin{array}{c}\text { 調査(3) 団らん室利用者 } \\
\text { アンケート調查 }\end{array}$ \\
\hline 調查方法 & \begin{tabular}{||l} 
訪問による生活協力員へのヒア \\
リング調查および過去の記録や \\
資料の収集。
\end{tabular} & $\begin{array}{l}\text { 団らん室の利用・活動時に参 } \\
\text { 与観察調查およ゙び参加者へ } \\
\text { のヒアリ゙ン゙調査。 }\end{array}$ & \begin{tabular}{|l} 
調查員および生活協力員の配布 \\
回收によるアンケー調査。記入 \\
困難者に関しては、調査員が聞 \\
き取りにてて記入*1
\end{tabular} \\
\hline 調查内容 & \begin{tabular}{||l} 
住宅概要、入居者の様子、団ら \\
室の使用状況、団らん室利用 \\
に至る絰緯など。
\end{tabular} & $\begin{array}{l}\text { 利用者の空間利用の様子、 } \\
\text { 活動の流れおよび内䛦の記 } \\
\text { 録など。 }\end{array}$ & $\begin{array}{l}\text { 団らん室の利用の仕方·空間評 } \\
\text { 価·利用者の生活状況·交流状 } \\
\text { 況など }\end{array}$ \\
\hline 調査期間 & 2007年 9 月 2008年 9 月 & $\begin{array}{c}\text { 2007年9月 2008年9月 } \\
\text { 合計34日間 } \\
\end{array}$ & $\begin{array}{l}\text { 2007年11月 12月 } \\
\text { 団らん室の利用·活動時 }\end{array}$ \\
\hline 調査対象 & $\begin{array}{c}\text { 団らん室の利用頻度の高い } \\
10 \boldsymbol{T}^{* 2} \text { 生活協力員 }\end{array}$ & $\begin{array}{l}\text { 団らん室の利用頻度の高い } \\
10 ヒ^{* 2} \text { の団らん窒8か所 }\end{array}$ & $\begin{array}{l}\text { 調査(2)の対象団らん室のうち協 } \\
\text { カが得られた } \\
\text { 利用者合計72人*3 } 7 \text { 所団らん室 }\end{array}$ \\
\hline
\end{tabular}

*1 調查員訪問晆に次席た゚った人については生活咕力員を通して配布回収した。

*2 ピアを供給する東京都内 50 区市の事業担当者に対するヒアリング調查結果に基づいて団らん室の利用がある 17ピアについて、現状把握の予備調査を行った上で、利用頻度が高く区市と生活協力員の調查許可の得られた 10ピアを選定した。

*3 利用者 72 人の内訳:ピア入居者 47 人・ピア入居者と同じ住楝に住む高齢者 14 人・ピア以外に住む 地域高齢者 8 人・無回答3人。

表 3 調査対象シルバーピアの団らん室状況

\begin{tabular}{|c|c|c|c|c|c|c|c|c|}
\hline & (1) S S 住宅 & (2) HM 1 住宅 (3) HM 2 住宅 & $\begin{array}{l}\text { (4) HM } 3 \text { 住宅 } \\
\text { (5) HM } 4 \text { 住宅 }\end{array}$ & (6) C K 住宅 & (7) A K 住宅 & (8)シルバーピアC S & (9)シルバーピアHS & (10) S ハイツ \\
\hline \begin{tabular}{|l|} 
面皘/ \\
配道階
\end{tabular} & $70.65 \mathrm{~m}^{2} / 1$ 階 & $140 \mathrm{~m}^{2} / 1$ 階 & $63.2 \mathrm{~m}^{2} / 1$ 階 & $74.19 \mathrm{~m}^{2} / 1$ 階 & $69.3 \mathrm{~m}^{2} / 5$ 階 & $56.6 \mathrm{~m}^{2} / 1$ 階 & 約 $60 \mathrm{~m}^{2} / 1$ 階 & $63.38 \mathrm{~m}^{2} / 6$ 階 \\
\hline \begin{tabular}{|c|} 
設備: \\
台所 \\
設備 $*$ \\
1 室 \\
\end{tabular} & $\begin{array}{c}\text { ミニキッチン·和室と } \\
\text { 洋室 }\end{array}$ & 厨房/和室と洋室 & ミニキッチン/洋室のみ & $\mid \begin{array}{c}\text { ミニキッチン/洋室 } \\
\text { のみ }\end{array}$ & 湯沸室/和室と洋室 & 厨房/和室と洋室 & なし/ロビースペース & 湯沸室/和室のみ \\
\hline \begin{tabular}{|l} 
開錠時 \\
間 $* 2$ \\
\end{tabular} & $7: 00 \sim 17: 00$ & $9: 00 \sim 17: 00$ & $9: 00 \sim 17: 00$ & $9: 00 \sim 13: 00$ & $9: 00 \sim 16: 00$ & 利用時のみ & 鍵なし & 利用時のみ (15:00 ) \\
\hline & Df & 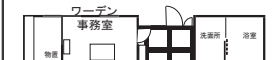 & & 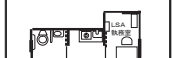 & — 広いテラス & $\downarrow^{\text {広い厨房 }}$ & & 7 \\
\hline 平面図 & & 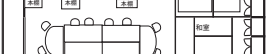 & 4 & 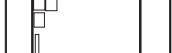 & 造 & 1 & & ] \\
\hline 主な & $\begin{array}{l}\text { 必要があれば、時間 } \\
\text { 外も柔軟に開放 }\end{array}$ & $\begin{array}{l}\text { 2棟で共有して利用。必要があれぱ } \\
\text { 時間外も柔軟に開放 }\end{array}$ & $\begin{array}{l}\text { 2棟で共有して利用。必 } \\
\text { 要があれば時間外も柔軟 } \\
\text { に開放 }\end{array}$ & \begin{tabular}{|l} 
時間外は、鍵の貸し \\
出し制による利用
\end{tabular} & 5階だが、広いテラスがある & $\begin{array}{l}\text { かなり広い㕌房スペース } \\
\text { がある }\end{array}$ & $\begin{array}{l}\text { 広いロビースペースをア } \\
\text { コーディオンカーテンで仕 } \\
\text { 切って利用 }\end{array}$ & $\begin{array}{l}\text { 団らん室内に共同浴場があ } \\
\text { る*3 }\end{array}$ \\
\hline
\end{tabular}

*1台所設備の分類は、以下の3つとした。(1ミミニキッチン1ロコンロと流し程度で、配膳スペースが十分なく、複数の作業には狭い。また、団らん室の1隅に配置されている。

2:湯沸室:1 2ロのコンロとシンク、調理台が有以、団らん室と仕切られた台所スペース。

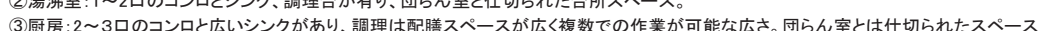

*2 開錠は、原則として生活協力員の勤務日 (土・日曜日・祝日・年末年始を除くすべて )だが、利用者の希望がある場合は、これ以外も開錠している。

*3 Sハイヘツは借上げで、オーナーがワーデンをしている。立替前は、銭湯だったため、オーナーの意向で浴場が残された。管理はオーナーによる。
10 ピアのうち、(2)HM 1 住宅、(3)HM 2 住宅、および(4)HM 3 住 宅、(5)HM 4 住宅についてはそれぞれ 2 つのピアで 1 つの団らん室 を共有して使用していたため、団らん室は 8 箇所を対象とした。団 らん室の面積は、ピアごとに差があるが、いずれも平均以上の広さ 注6) である。配置階は、接地性のある配置が、6 ピアでみられる。 団らん室の設備状況には大きな差があり、特に、台所スペースでは シンクの大きさや熱源の違いが顕著である。

\section{（5）団らん室利用者の状況}

利用者へのアンケート調査結果では、利用者は女性が 52 人 (72. $2 \%)$ と多く、平均年齢は 74 歳である。利用者のうち、ピア入 居者は 47 人 $(65.3 \%) 、$ 同じ住棟の一般住居入居者は 14 人 (19.4\%)、 それ以外の地域居住者は 8 人 (11.1\%) である。

表 2 調查対象シルバーピアの概要

\begin{tabular}{|c|c|c|c|c|c|c|c|c|c|c|c|c|c|c|c|c|c|}
\hline \multicolumn{2}{|l|}{$\begin{array}{c}\text { 調查対象 } \\
\end{array}$} & \multicolumn{5}{|c|}{ 住楝状況 } & \multicolumn{5}{|c|}{ ピア入居者状況 } & \multicolumn{6}{|c|}{ 生活協力員 } \\
\hline $\begin{array}{l}\text { 調查シルバー } \\
\text { ピフ(所在地) }\end{array}$ & 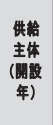 & 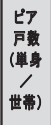 & 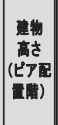 & 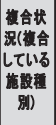 & 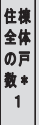 & 住棟 & 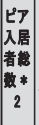 & 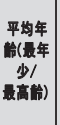 & $\begin{array}{l}\text { 要 } \\
\hat{\Uparrow} \\
\text { 萑 } \\
\text { 者 } \\
\end{array}$ & 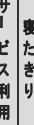 & 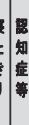 & 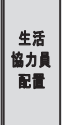 & 勘䟦場) & 人性 & $\begin{array}{l}\text { 年 } \\
\text { 柃 } \\
\text { 歲 }\end{array}$ & 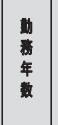 & $\begin{array}{l}\text { 資 } \\
\text { 格 }\end{array}$ \\
\hline $\begin{array}{l}\text { (1)SS住宅 } \\
\text { (i工東区) }\end{array}$ & $\begin{array}{l}\text { 都常 } \\
\text { (2002) }\end{array}$ & $\begin{array}{l}24 \\
(24 / 0)\end{array}$ & $\mid \begin{array}{c}14 \text { 階建 } \\
(2-6)\end{array}$ & $\begin{array}{l}\text { 䧸 } \\
\text { (一般) }\end{array}$ & 272 & 1棟 & 24 & $\begin{array}{c}75 \text { 歲 } \\
(70 / 89)\end{array}$ & 4 & 100 & 1 & $\begin{array}{l}7-\overrightarrow{T_{2}} \\
\text { 常䝬 }\end{array}$ & 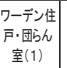 & 1 女 & 60 & 5年ћ & 特にない \\
\hline $\begin{array}{l}\text { 2HM1住宅 } \\
\text { (東村山市) }\end{array}$ & $\begin{array}{c}\text { 都党 } \\
(2000)\end{array}$ & $\begin{array}{c}20 \\
(16 / 4)\end{array}$ & $\begin{array}{c}10 \text { 階建 } \\
(1-4)\end{array}$ & $\begin{array}{l}\text { 䧸 } \\
\text { (-般. } \\
\text { 車便) }\end{array}$ & 44 & 团地 & 24 & 不明 & & & & 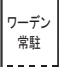 & Гーデン倠 & 1 女 & 61 & 8年 & 侏にない \\
\hline $\begin{array}{l}\text { 3HM2住宅 } \\
\text { (東村山市) }\end{array}$ & $\begin{array}{c}0 \\
\text { 都常 } \\
(2000)\end{array}$ & $\begin{array}{c}20 \\
(16 / 4)\end{array}$ & $\begin{array}{l}7 \text { 7階建 } \\
(1-7)\end{array}$ & $\begin{array}{l}\text { 居雄 } \\
\text { (-般. } \\
\text { 車仗) }\end{array}$ & 44 & 团地 & 24 & $(73 / 88)$ & 0 & $7 \mid 0$ & 2 & 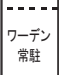 & $\begin{array}{c}\bar{P} \cdot(⿴ 囗 十) h \\
\text { 窐(1) }\end{array}$ & 1 女 & 67 & 4年 & 特になな \\
\hline $\begin{array}{l}\text { HM3住宅 } \\
\text { 树山市) } \\
-0 .\end{array}$ & $\begin{array}{l}\text { 都黨 } \\
\text { (2004) } \\
\end{array}$ & $\begin{array}{c}19 \\
(15 / 4) \\
\end{array}$ & $\begin{array}{l}4 \text { 㳻建 } \\
(1-4) \\
-\end{array}$ & 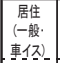 & 54 & 団地 & 23 & 7.65歲 & & & & 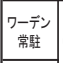 & 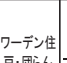 & 1 女 & 62 & 4年 & 特にない \\
\hline $\begin{array}{l}\text { 5)HM4住宅 } \\
\text { (東村山市) }\end{array}$ & $\begin{array}{l}\text { 都黨 } \\
\text { (2004) }\end{array}$ & $\left.\begin{array}{c}19 \\
(14 / 5)\end{array}\right]$ & $\begin{array}{l}\text { 4階建 } \\
(1-4)\end{array}$ & 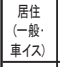 & 48 & 团地 & 23 & $(65 / 92)$ & $1^{4}$ & ${ }^{4}$ & 1 & \begin{tabular}{|c|}
$7-テ ゙ ン$ \\
常駐
\end{tabular} & 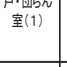 & 1 女 & 50 & 4年 & 特にな \\
\hline 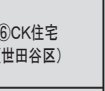 & 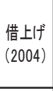 & $\begin{array}{c}19 \\
(17 / 2)\end{array}$ & $\begin{array}{l}3 \text { 階建 } \\
(1-3)\end{array}$ & $\begin{array}{l}\text { 䧸 } \\
\text { (障害) }\end{array}$ & 20 & 1棟 & 21 & $\mid \begin{array}{c}72 \text { 歲 } \\
(69 / 80)\end{array}$ & 不 & 不 & 1 & 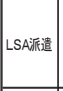 & $\begin{array}{l}\text { 团らん宰 } \\
\text { (生活相铞 } \\
\text { 至)(1) }\end{array}$ & 4 女 & \begin{tabular}{|c|}
$36 /$ \\
$60 /$ \\
$65 /$ \\
51
\end{tabular} & 4 年 & 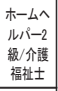 \\
\hline $\begin{array}{l}\text { DAK住宅 } \\
\text { (千代田区) }\end{array}$ & $\begin{array}{l}\frac{\text { 区立 }}{(2004)} \\
\text { (204) }\end{array}$ & $\begin{array}{c}21 \\
(18 / 3)\end{array}$ & $\begin{array}{l}12 \text { 階建 } \\
(5-12) \\
\end{array}$ & $\begin{array}{c}\text { 居住 } \\
\text { (每子) } \\
\text { 屁間荡設 } \\
\end{array}$ & 23 & 1榑 & 24 & $\left|\begin{array}{c}\text { 77歲 } \\
(72 / 88)\end{array}\right|$ & 7 & 3 & 1 & 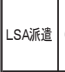 & 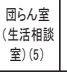 & 女 & 47 & 4年 & \begin{tabular}{|c|} 
介濩福社 \\
\pm \\
\pm
\end{tabular} \\
\hline $\begin{array}{l}\text { 8シルルトーピアC } \\
\text { S(調布市) }\end{array}$ & $\begin{array}{c}\text { 都常 } \\
\text { (1993) }\end{array}$ & $\begin{array}{c}15 \\
(10 / 5) \\
\end{array}$ & $\begin{array}{l}\text { 3階建 } \\
(1-3)\end{array}$ & な & 15 & 1棟 & 20 & \begin{tabular}{|c|}
688 藏 \\
$(82 / 94)$
\end{tabular} & 5 & 1 & 1 & $\mid$ & $\begin{array}{c}\text { T-デ准 } \\
\overline{\bar{P}}(1)\end{array}$ & 1 女 & 63 & 7年 & $\begin{array}{l}+4 \hat{1} \\
\mu, i-2.3 \\
\text { 级 }\end{array}$ \\
\hline $\begin{array}{l}\text { 9シルパーピアH } \\
\text { S(港区) }\end{array}$ & $\begin{array}{l}\text { 区立 } \\
(1993) \\
\end{array}$ & \begin{tabular}{|c|}
17 \\
$(17 / 0)$ \\
\end{tabular} & \begin{tabular}{|l|}
5 \\
階建 \\
$2-5)$ \\
\end{tabular} & な & 17 & 1棟 & 17 & \begin{tabular}{|c|}
$\begin{array}{c}81 \\
(68 / 92)\end{array}$ \\
\end{tabular} & $t^{\prime}$ & 7 & ) & |LSA常駐 & $\begin{array}{c}\begin{array}{c}\text { LSA隹 } \bar{~} \\
(1)\end{array} \\
\end{array}$ & 1 女 & 67 & 1年 & 看濩師 \\
\hline $\begin{array}{l}\text { (10Sハイツ } \\
\text { (㐬川区) }\end{array}$ & $\begin{array}{l}\text { 借上|f } \\
\text { (1992) }\end{array}$ & \begin{tabular}{c|}
34 \\
$(29 / 5)$ \\
\end{tabular} & \begin{tabular}{|l|} 
7階建 \\
$(1-6)$
\end{tabular} & $\begin{array}{c}オ-+- \\
\text { 住戸 }\end{array}$ & 35 & 1槙 & 39 & \begin{tabular}{|c|}
76 歲 \\
$(68 / 92)$
\end{tabular} & 6 & 10 & 2 & \begin{tabular}{|l|} 
Dーデン \\
常駐 \\
\end{tabular} & 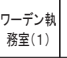 & 男 & 55 & 16年 & 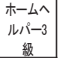 \\
\hline
\end{tabular}


表 4 団らん室の利用内容分類

\begin{tabular}{|c|c|}
\hline & 内容 \\
\hline A: 製作 & 手芸などの作品製作などを中心とした活動利用 \\
\hline B: 飲食 & 飲食を主目的とした活動利用 \\
\hline C: 趣味 & 囲基·合唱など㛎楽·趣味活動を主目的とした活動·利用 \\
\hline $\mathrm{D}$ :体操 & 体を動かすことを目的とした活動利用 \\
\hline $\mathrm{E}:$ 学習 & 情報収集や学習することを主目的とした活動利用 \\
\hline$F:$ その他 & A Eのいずれにも該当しないその他の利用 \\
\hline
\end{tabular}

表 5 団らん室の利用頻度分類

\begin{tabular}{|c|c|}
\hline & 内容 \\
\hline 定期利用 & 曜日・時間を定めて定期的に集まって利用する \\
\hline 不定期利用 & 必ず行うことは決まっているが、日時については随時決定して利用する \\
\hline 臨時 & 生活協力員や入居者の発案で臨時I行うことが決まる利用 \\
\hline
\end{tabular}

\section{4. 団らん室利用の現状}

\section{（1）利用内容および、利用頻度からの分類}

生活協力員へのヒアリング調查、および団らん室参与観察調查に よって明らかになった利用内容の詳細を表 6 に示す。利用内容を主 な利用目的から分類すると、A.製作、B. 飲食、C.趣味、D.体操、 E. 学習、F、その他の 6 種類に分類することができる (表 4 )。また、 利用形態としては、明確な目的を持って企画された利用と特別な目 的のない立寄が確認できた。目的のある企画は、その利用頻度によ って定期利用、不定期利用、臨時利用に分類できた。そのうち、休 止または消滅した利用も確認できた(表 5 )。団らん室の利用内容と 利用頻度別に見た企画数を図 1 に示寸。

団らん室の利用で最も多いのは、飲食を主目的と寸る利用で、つ いで、製作になっている。飲食利用は、昼食や夕食を目的とし、調 理は、生活協力員を中心に利用者が分担して作業するケースや、市 販品を担当者が買い出しするなど、利用者間で協力が見られる。ま た、飲食を主目的としていない活動でも、ほぼ全てでお茶とお菓子 等による休賃が行われていることは興味深い。これらは、お裾分け やお土産などの差し入れも多く、近所付き合いが団らん室で展開し ていると言える。次いで多い製作では、女性を中心にした手芸が多 い傾向が読み取れる。男性の参加が多いのは趣味の活動で、囲碁や マージャンがある。体操や学習を主目的とする利用はわずかだが、 介護保険制度による介護予防教室の会場として利用されている。

次に、利用頻度から考察する。最も多い定期利用では、製作など のサークル活動、飲食のために、隔週利用するなど生きがい作りや 情報交換など利用者間の交流が活発に行われている。また、定期利 用は、目的を共有寸る数人の利用者での集まりが多いが、不定期利 用は、ピア全体に参加を呼びかけて行う人数の多い利用が多いとこ ろに特徵が見られる(図 2 )。立寄は(表 7 )、団らん室の開錠時には、 7 か所の団らん室で確認できた。団らん室をピア以外一外部開放し ているところでは、ピア入居者以外の立寄も確認でき、特に、毎日 決まった時間に立寄ことが日課となっている高齢者もいることから、 団らん室が高齢者の居場所としての役割を果たしていると考えられ る。団らん室が施錠されている時間帯でも、生活協力員がいる場合 は滞在している場所注7) への立寄が確認できた。「団らん室に生活協 力員がいる方が良いか」どうかについては、利用者アンケートでも

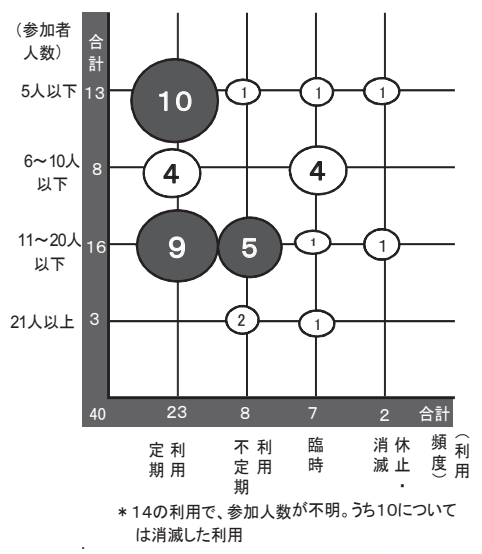

図 2 利用頻度と参加人数から 見た企画数 $(n=40)$

から見た企画数 $(n=54)$

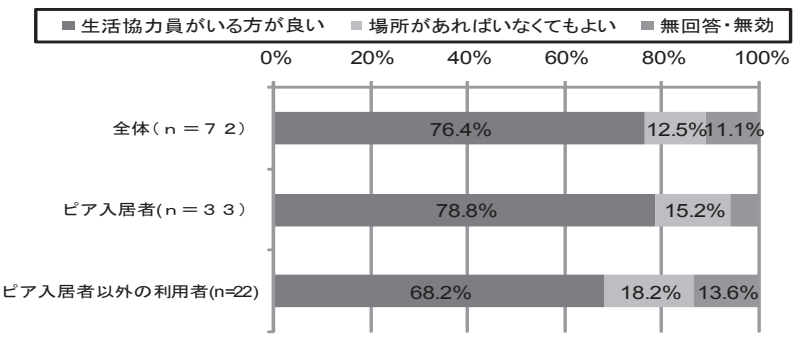

図 3 入居者別にみた団らん室に生活協力員がいることの評価 (団らん室利用者アンケート結果)

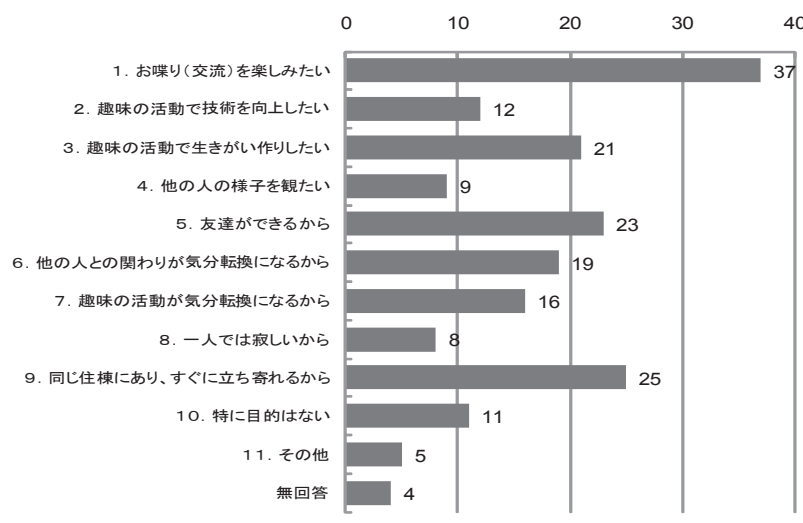

図 4 団らん室を利用寸る理由 $(\mathrm{n}=52$ 複数回答 $)$

(団らん室利用者アンケート結果)

7 割以上が「生活協力員が団らん室にいる方が良い」と回答してい る（図 3)。また、利用理由についてみると「お喋り（交流）を楽し みたい」「同じ住棟にあり、寸ぐに立ち寄れる」「友達ができる」と いった回答が多くみられる（図４）。身近な場所にすぐ立ち寄れる場 所があること、さらにそこにいけば生活協力員がいるなど、利用や 立寄を促す条件が整っていると考えられる。また、臨時利用がある ピアでは、定期や不定期利用での利用者の情報交換や発案によって、 実現した利用が多く、団らん室の利用によって、利用者の交流が発 展的に広がっていることが確認できる(表 6 )。逆に、途中で頻度が 減ったり、消滅した利用もある。これらは、開設してすぐに始まっ た企画が多い(表 6 )。生活協力員へのヒアリング調查によると、現 在、継続して行われている定期および不定期利用でも、体調不良な どで参加者の減少傾向が指摘され、今後が危惧される。 


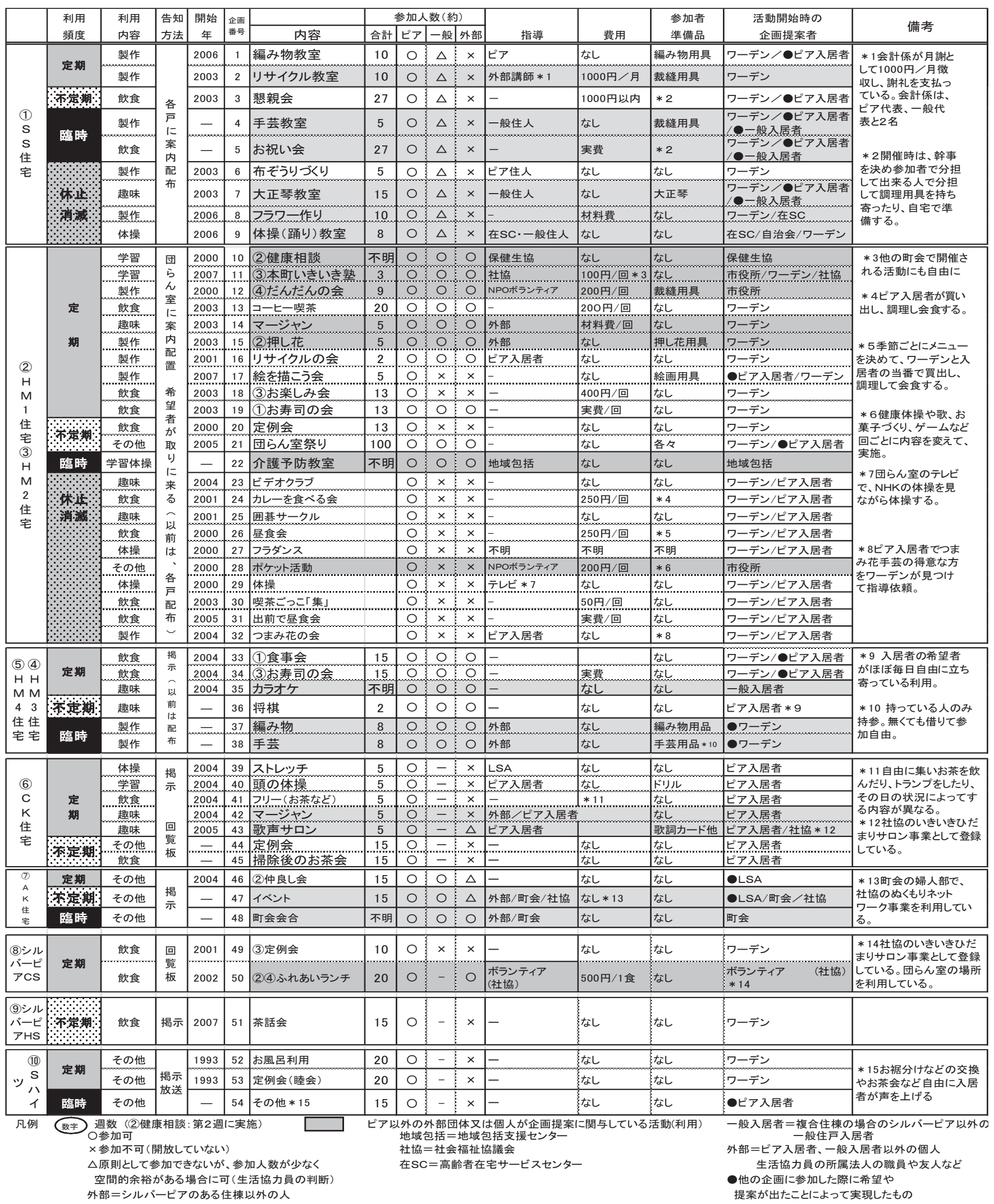


表 7 団らん室への立寄の有無と開錠状沉・生活協力員の配置状況・外部開放状況（団らん室利用者アンケート結果）

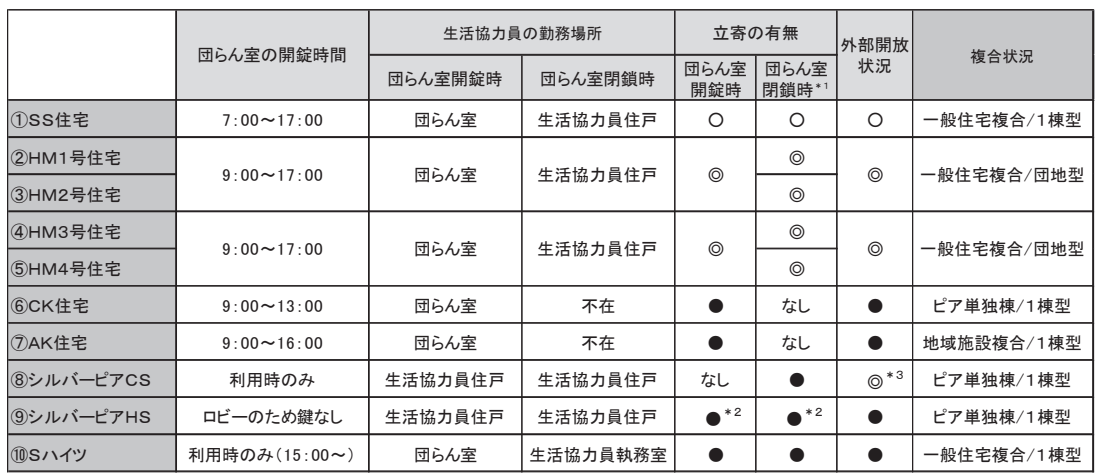

(外部開放状況)

๑ピア入居者のみで使用

○ピア入居者および同じ住棟のピア以外の入居者も利用

○ピア入居者以外の地域高齢者の利用もある

( 立寄)

・ピア入居者のみが立寄

○ピア入居者および同じ住棟のピア以外入居者も立寄

○ピア入居者以外の地域高齢者の立寄もある

*1 団らん室閉鎖時については、生活協力員が滞在する 場所への立寄り状況を記入

*2 ロビースペースのため開錠の状況ではなく。

企画の開催時の立寄状況を記入

*3 シルバーピアCSは、ピア入居者のみ参加の定例会と

地域高齢者のみが参加する㡺食会の利用のみで

地域高魿者のみが参齢者に団らん室を開放しているのは

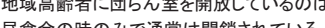

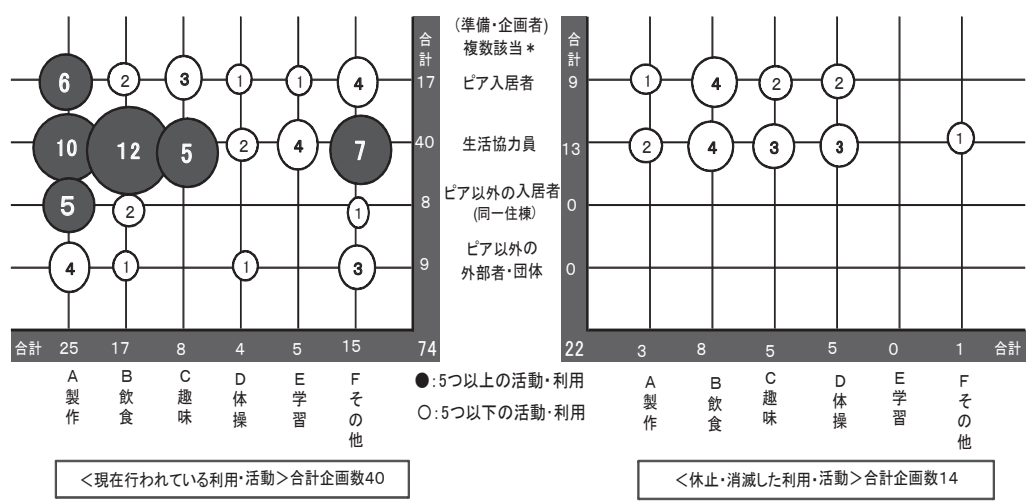

* 準備·企画者は人数ではなく、所属、団体ごととする。例えばピア入居者2名·生活協力員1名」よる準備·企画の場合は、ピア入居者1と生活協力員11該当する。

図 5 利用・活動のための企画・準備者 (複数該当)

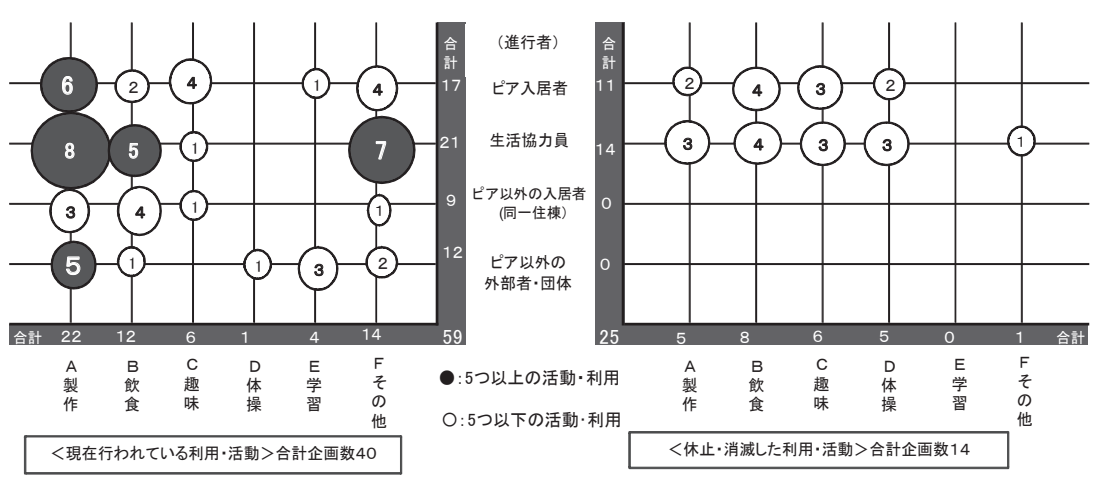

図 6 利用・活動の進行者 (複数該当)

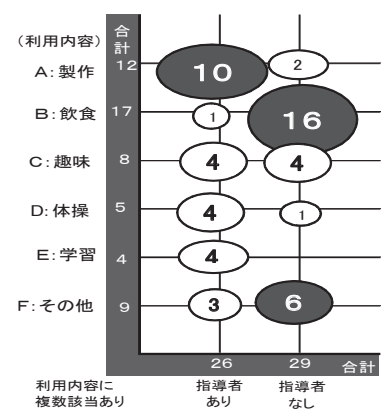

図 7

利用内容別指導者の有無

から見た利用数 $(n=54)$

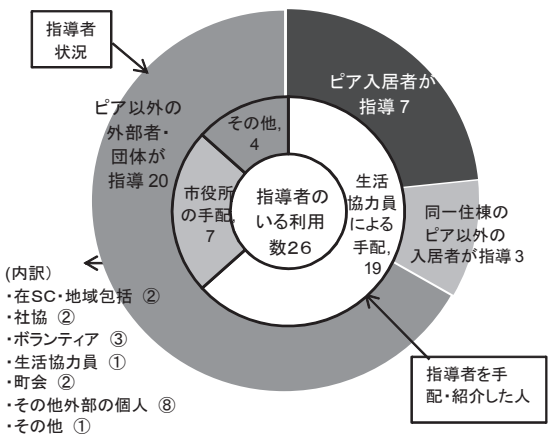

*1つの利用・活動で指導者が複数いる場合を含む

図 8 指導者の内訳とその手配者

\section{（2）活動や利用の企画と運営経緯}

団らん室の利用がどのようなきっかけで企画されて始まり、定着 または消滅したかについて考察する。利用にかかわる企画提案およ び準備をした者、さらに利用や活動に際して中心となって進行・実 施した者（以下、企画提案・実施者）を利用内容別に示したものが 図 5、6である。特に、現在行われている利用と既に消滅・休止し た利用を比較分類する。さらに、指導者の有無といる場合の内訳を 図 $7 、 8$ 亿示寸。ほとんどの利用で生活協力員が主体的に関与して いることが認められる。ヒアリング調查から、いずれの生活協力員 も入居者の引きこもり防止と相互交流を心がけ、情報収集や計画を 行ってきたことがわかった。企画に生活協力員が関与していないの は、10（全活動の $18.5 \%$ ）のみである。このうち、ピア入居者のみ による企画はなく、社会福祉協議会（以下、社協）によるボランテ
イア、市役所、町会など地域に密着した団体の関与が確認できる（図 8)。これらは、(2)(3)HM1.2 住宅等に見られ、開設時に市役所から 社協のボランティア組織や地域包括支援センター（以下、地域包括） などを紹介され、関わりを持っていることが認められた。特にワー デンは、企画に結び付く専門知識やL S A の所属法人のような人脈 も少ないため、情報収集や積極的な働きかけなど、企画、運営全般 の業務が個人の努力に依存せざるをえないが、区市役所などの公的 機関から外部団体の情報を事前に得られた点は、非常に有効だった という意見がヒアリングで指摘されている。(7) A K 住宅の L S A の 場合は、所属する社会福祉法人が地域との結びつきを重視しており、 町会、婦人会との交流がみられ、L S Aのみならず地域全体でピア 入居者を見守る体制を整えている様子もうかがえる。この他、町会 や自治会との結びつきも 4 ピアの団らん室で見られる。いずれも、 
混在型であり、地域に住むことを重視し、地域に開かれた利用がさ れている。居住系施設との複合や、住棟が複数棟構成の場合は、開 放した利用がスムーズに行われているといえる。 8 シルバーピア C Sでは、唯一、ピア以外の地域の人だけを対象に、給食サービスが 実施されており、団らん室の場所を地域拠点として開放し、円滑に 利用している注8)。この背景には、企画運営している社協のボラン ティア団体の力が大きいことが観察調查で明らかにされた。飲食利 用では、特別な指導者は必要ないが、食事の準備・手配・後片づけ などの作業・段取りが必要であり、生活協力員が中心に行う場合や ボランティアなどと協力する利用が多いことも認められる。製作や 趣味では指導者がいる場合が多く、指導者の内訳を見ると外部者・ 団体が多いことが分かる。しかし、身近なピア入居者の中にも、仕 事や趣味・特技を生かして指導する人材がいることも確認できる。

次に、利用の継続性について見る。企画数は開設年度が早いほど 多いわけではなく、団らん室ごとでその時々に応じた柔軟な企画が されてきたことが生活協力員へのヒアリング調查でわかった。この うち、(1)SS 住宅、(2)(3)HM1.2 住宅では、休止・消滅した活動が確認 できた(表 6 )。外部団体が関与する利用が比較的定着しているのに 対し、ピア入居者のみの閉鎖的な使用が休止・消滅している。これ は、高齢化による身体負担の増加や経費に関わるトラブル、限られ た利用者間でのトラブルが原因であることがワーデンへのヒアリン グ調査で指摘された。このうち、いくつかの活動は、ワーデンの働 きかけで合併吸収し、形式を変えて再開している。再開に関しては、 混在住棟の特徵と都営住宅が近接する地域状況を考慮して、外部に 開いた形で利用を目指したワーデンの工夫がみられる。ピア入居者 のみの利用の場合は、限られた入居者でトラブルや高齢化による身 体的負担の増加によって利用が消極的になる傾向が明らかで、外部 者の関与や参加がある場合は、利用が継続しやすい傾向があると考 えられる。また、指導者や事前準備・企画者がきちんといる方が、 企画を継続しやすい傾向が認められる。

\section{（3）団らん室利用の外部開放状況}

団らん室利用の経緯や関連する状況から、混在する一般住宅や近 隣地域の外部者に開放された使用もされている。また、ピア入居者 や生活協力員以外の外部者が企画に関わり様々な活動を提案し、継 続的に新たな情報を提供することで、ピア入居者の興味関心を引き 活動意欲を促進している。団らん室は原則としてピア入居者のみの 使用とされているが、実際にはピア状況に応じた柔軟な外部開放に より円滑な活用に結び付いているといえる。

各団らん室の利用について、企画提案・実施者と外部開放性の関 連を整理したものが図 9 である。横軸に企画に関与した人や団体を 示し、縦軸に使用者の開放性を示している。これによると、(A) ピ ア内部で完結する企画、(B) ピア以外の外部者などが企画にかかわ りピア入居者が利用する企画、(C) ピア内部で企画し、外部にも利 用開放している企画、さらに、（D）ピア以外の外部者が企画にかか わり、外部にも利用開放している企画の 4 つに分類できた。

（A）（C）で企画が多くなっている。（A）は企画者も利用者も ピア内部で完結しているが、ピア入居者が積極的に企画し定着して いるのは、住棟構成が 1 棟型で形態が単独型のピア団らん室の企画 である。一方、約半分が消滅や合併した企画である。これらは、(2) (3) HM 1.2 住宅で開設後比較的早期に始まった企画が多いが、そ
のうちいくつかは利用者を外部開放することで新たな企画として定 着している企画もある。（C）では、定着している企画が多くなって いる。これは、住棟構成が団地型で形態に複合が見られる(2)(3)HM 1. 2 住宅、(4) (5)HM 3.4 住宅や、形態が複合の (1) S S 住宅など の企画で多く、複合住戸や地域との結びつきを持ちながらの利用と いえる。(D)では、町会や自治会との結びつきを持ちながら企画し、 利用も広く地域に開放している。団らん室が地域拠点の「場所」と なっている企画と考えられる。

\section{（4）団らん室空間の使い方}

参与観察調査より、団らん室空間の利用の仕方について考察する。 団らん室の広さや仕様は、それぞれ異なる。消滅・休止した活動以 外の空間の使い方をその特徴ごとに分類し、表 8 に示す。

活動の開始から終了までに、席を移動する利用者はわずかである。 和室のみの利用はなく、全てメインになる洋室を使用している。同 時に目的の違う複数のグループをつくり着席する場合は、複数の利 用を同時並行で行い、 $2 \sim 5$ 人程度の少数で机とイスを無理なく配置 して活動している。空間的な問題はなく、グループ相互に会話に加 わり情報交換する場面も見られる。

一つの目的で使用する場合でも、団らん室全体を使って着席する 場合と、グループごとに着席する場合とがある。全体利用は、ピア 全体の懇親会や定例会などが多く、和室部分にも机とイスを配置し ている。この場合、着席できる空間の広さによって参加者を制限し なければ身動きが取れない(1) S S 住宅のようなケースもあり、ワー デンの裁量でピア入居者を優先している様子が確認できた。一方、 面積の最も広い(2)(3HM1. 2 住宅の団らん室では、地域の人々の利 用があっても空間的な余裕があり、団らん室ごとに差が見られる。 逆に参加人数の少ない利用では、部分的に空間を使い、障子やパー ティション、家具などで空間を区切って利用している。中でも、 (6) C K 住宅では、空間は広いものの利用者が少ないため、必要な空間 だけを仕切る工夫がしたいとう意見もあげられた。実際の利用者に よる空間評価は、広さ (図 10 ) は 3 つ団らん室利用者全員が「ち ようど良い」と高く評価している。「もう少し広い方が良い」という

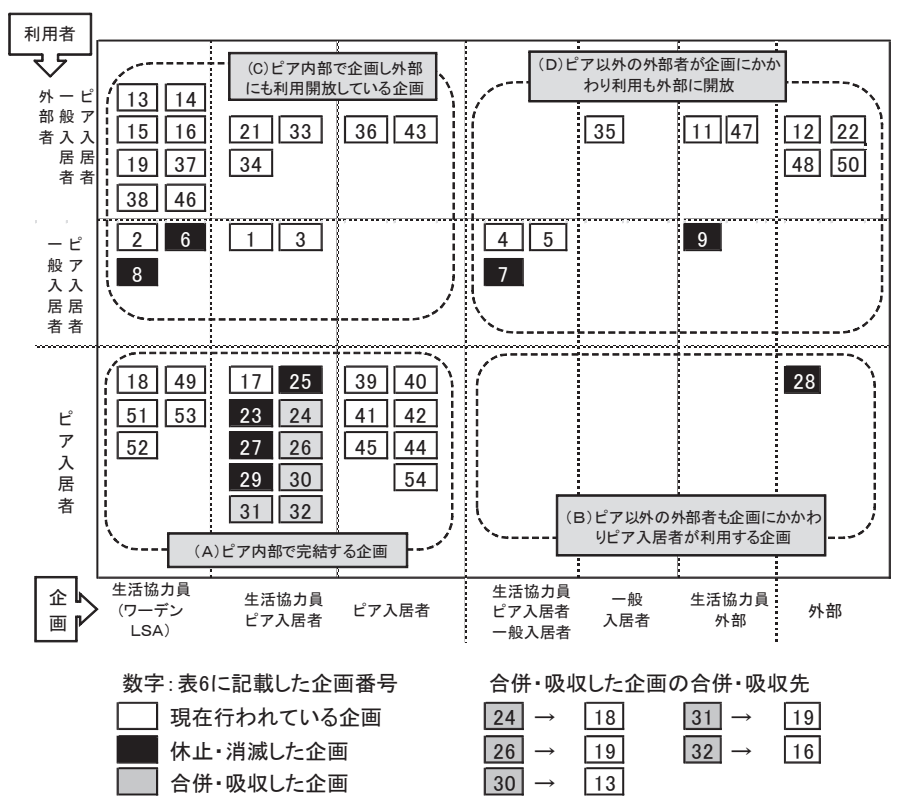

図 9 団らん室利用の企画者と利用者からみた企画の外部開放状況 
表 8 団らん室空間の利用例

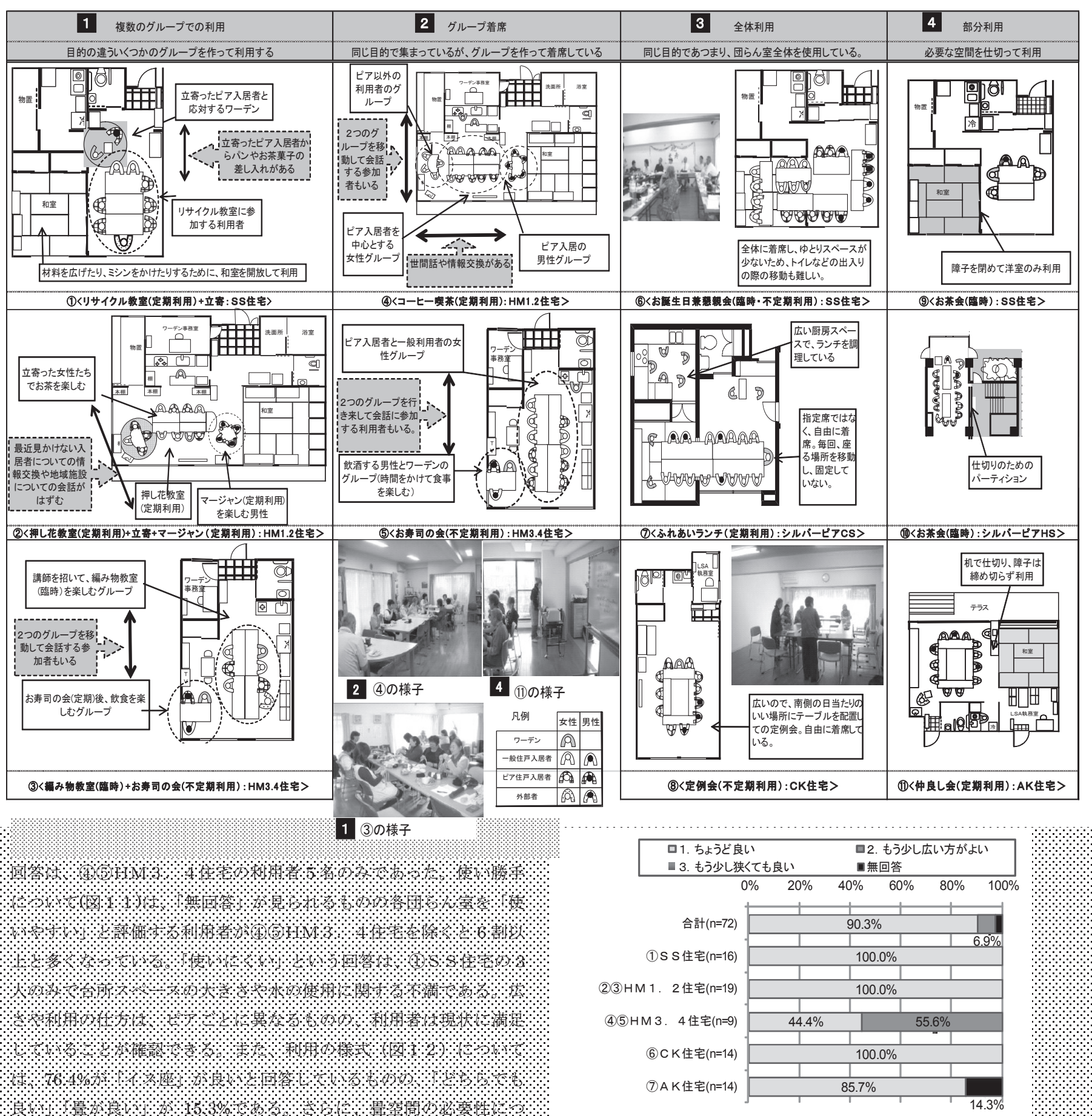

良い」「畳が良い」が $15.3 \%$ ある。さらに、畳空間の必要性につ いては「あった方が良い」が 40.3\%で「必要ない」は $25.0 \%$ 、実 際に畳にユ力座様式で団らん室を利用する活動はないものの、畳が あることへの愛着が大きいものと推察される。

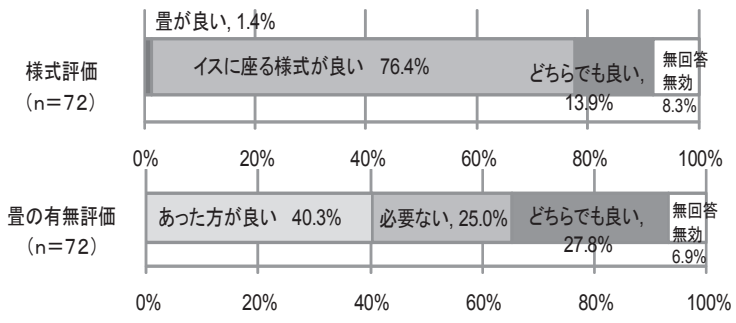

図 12 利用者の空間評価(利用者アンケート調査)
図 10 団らん室ごとにみた広さの評価 (利用者アンケート調查)

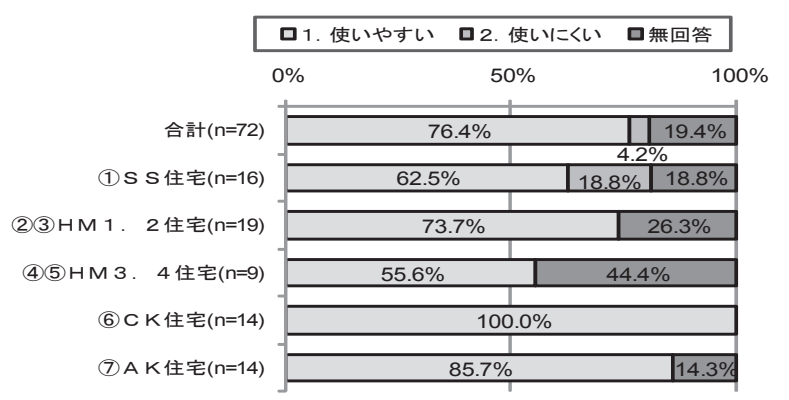

図 11 団らん室ごとにみた使い勝手の評価(利用者アンケート調査) 


\section{5. まとめ}

以上の分析から、団らん室利用者、企画と運営に関わる人の状況 および空間の使い方について、以下のことが明らかにされた。

(1) 団らん室は、生きがい作りや相互交流などのために重要な場所 として利用されている。地域の高齢者の居場所としての機能も果た し、ピア入居者とピア以外の地域高齢者の交流の広がりに相乗的な 効果が期待できる。気軽に立ち寄れる場所があること、そこに行け ば生活協力員が常時いるという状況が単身高齢者にとって特に重要 な団らん室利用要因になっている。

(2) 団らん室の利用企画は製作や飲食が多く、事前準備・指導進行 などの中心人物・団体の存在が極めて重要で、利用が継続展開して いく要因と言える。企画のほとんどが生活協力員の積極的な働きか けと情報収集、計画によって実現しているが、個人委託のワーデン の場合は、情報収集や支援が得にくく、大きな負担である。そのた め、市役所などからの情報提供が有効で、地域に密着した組織との かかわりは、高齢者と地域との結びつきにもなっていることが確認 できた。

(3) 団らん室の利用者は、ピア内部に限定した利用の場合よりも、 広く外部に開放し、地域高齢者などの参加を募るほうが、企画も定 着し、継続する可能性が高い。企画の定着・継続には、高齢者の身 体状況や経済的負担への配慮が重要である。また、ピア以外への開 放利用では、団らん室の配置(接地性)、住棟の混在状況、住棟周辺 の高齢者状況を考慮して適した利用計画を立てることが有効である。 (4) 団らん室空間は、参加人数と目的、広さに応じて工夫した利用 が確認できた。高齢者は、小グループでの利用とピア全体で行う一 定人数での利用が多いことが分かった。そのため、参加者の人数、 空間面積に応じた利用計画をたてることが有効である。

(5) 団らん室は、和室スペースをユカ座で使用する例はなく、畕の 上にイス、テーブルを使ってイス座で利用していた。身体負担の少 ないイス座を用いることで畳空間も柔軟に使用されている。

以上の知見から、ピア内部に団らん室利用を限定するという制限 は、団らん室の有効活用や今後の地域拠点となりうる可能性を阻む ものであると言わざるを得ない。ピア住宅は地域に数多く点在し、 ストックとしての価值も大いに期待できるにも関わらず、その団ら ん室はほとんど利用されていない現状を改善し、規模に応じた多機 能空間として位置づける意味は非常に大きいと考えられる。そのた めには、団らん室に関するシルバーピア事業要綱を見直し、ピア周 辺の地域状況を把握している各自治体が団らん室の有効活用のため の要因を具体的に検討することが重要である。既存ピアの団らん室 の空間面積に応じた利用方法、事前準備、指導者などの中心となる 組織や地域ごとの特徵を反映させた利用システムを具体的に計画す ることが急務と考えられる。その際、社協や自治会、町会などの組 織との有機的なかかわりを積極的に検討していくことが地域全体で 高齢者を見守る点からも効果的である。また、本論文では、利用頻 度の高い団らん室のみを調查対象として取り上げたが、利用頻度の 低い団らん室にも着目し、利用されない要因を具体的に抽出し、比 較検討することも今後の課題である。

\section{参考文献}

1 ) 西川加禰 : シルバーハウジングの住戸配置計画に関する研究, 日本建築学
会大会学術講演梗概集 $\mathrm{E}-2, \mathrm{pp} 297 \sim 298,2001.9$

2 ) 小田部篤, 松井壽則 : シルバーハウジングの計画に関する研究その 7 -シ ルバー世帯と一般住戸居住者の交流状況, 日本建築学会大会学術講演梗概 集 E-2, pp331〜332, 1999.9

3 ) 厳平, 横山俊祐 : シルバー八ウジングにおける近隣交流の特性と空間的課 題一高齢者の豊かな居住環境想像に関する研究その $2-$, 日本建築学会計 画系論文集 No. 554,pp109〜116, 2002.4

4 ) 伊佐地大輔, 上野淳 : シルバーピア居住者の生活展開と生活領域の拡がり に関する研究, 日本建築学会計画系論文集 No569, pp39〜45, 2003. 7

5 ) 大塚順子, 定行まり子 : シルバーピアの住棟形態から見た団らん室の利用 に関する研究，日本建築学会計画系論文集 No638, pp743〜 750, 2009. 4

6 ) 大塚順子, 定行まり子：高齢者集合住宅における生活相談団らん室の有効 活用に関する考察一東京都シルバーピア事業の研究 (その 3 ) 一, 日本建築 学会大会学術講演梗概集 E-2,pp67～68, 2009. 8

注

注 1 ) 東京都シルバーピア事業要綱では、「集合住宅には、利用者同士、ま た地域住民等との交流を促進するための集会室を設置することがのぞまし い」とだけ記され、団らん室の設置義務はない。団らん室の設置および運 営に関してはピアを設置する自治体に委礼られており、ピア入居者のみに 利用を限定することが前提となっている。

注 2 ） シルバーピア事業では、見守りを行う福祉人材について名称が様々使 用されている（ワーデン、管理人など）また、シルバーハウジングプロジ エクトでは、生活援助員、ライフサポートアドバイザー(LSA)などと呼称さ れる。本研究では、シルバーピア事業要綱に基づく場合はワーデン、生活 援助員要綱に基づく場合は LSA とし、両者を総称する場合は、生活協力員 を用いる。

注 3 ) 収集したシルバーピア事業計画書（収集数 436 ピア全数 486 ピア収集 率 $89.7 \%$ ）に記載された平面図による分析と生活協力員調查（2008 年 8〜 9 月実施、協力の得られた 37 区市町村 320 人を対象として実施、回答 245 人回収率 $76.6 \%$ ）の結果による。利用頻度の高い団らん室は、面積 $60 \mathrm{~m}^{2}$ 以上の広さがあり、生活協力員が鍵を管理し、使用時のみ開放寸る団らん 室が多いことが明らかとなった。詳細については、参考文献 5 ）にて報告 している。

注 4） シルバーピアを供給している東京都内の 51 区市を対象として、現状 把握のためのヒアリング調査を 2006 年に実施した。協力が得られたのは、 50 区市（瑞穂町をのぞく）で、事業担当者より団らん室の使用状況などを 聴取した。

注 5 ）＼cjkstart注２）に示すように、現在のシルバーピアにはシルバーピア事業開始 当初導入されたワーデンと後から導入された国が実施するシルバーハウジ ング・プロジェクトによるL S A とが存在し、ピアごとにワーデン、L S Aの違いがみられる。両者は名称だけではなく(1)委託形式(2)資格の有無(3) 勤務体制などに違いがある。これらは、根拠となる要綱に規定されている もので、ワーデンは、ピア内に専用住戸を持ち、家族とともに常駐し、個 人委託のケースが多い。一方、L S A は常駐する専用の住戸は無く、社会 福祉法人などへの法人委託によって派遣されるケースが多い。また、勤務 内容についても、ワーデンは、専門知識の有無が採用要件ではなくあくま でも隣人としての見守り業務だけであるのに対し、LSA は高齢者の生活全 般に対する相談助言なども業務に規定され専門的な対応を求められている （詳細については、大塚順子・定行まり子「東京都シルバーピアにおける 生活協力員の配置状況と今後の役割一区市町村担当者調查から一」日本家 政学会誌, Vol. 59, No. 11, pp911～921. 2008 で報告している。）こうした、 現状を考慮して行った既往調査（参考文献 5 ）において、団らん室の利用 が管理を担当する生活協力員の配置状況と関連するという知見を得て本論 文においても生活協力員の現状を把握し、ヒアリング調査を実施した。

注 6 ) 東京都内シルバーピアの団らん室面積の平均は 53.3 m²゙るる。

注 7 ）生活協力員のうち、ワーデンについては本来、勤務時間中はワーデン 用専用住戸に常駐し、必要がある場合に適切な対応をすることがシルバー ピア要綱で規定されており、団らん室の鍵の管理は業務であるものの、団 らん室に常駐することは義務づけられてはいない。一方、LSAについては、 LSA 用の専用住戸が設置されていない場合が多いため、団らん室内に設置 された執務室に勤務時間のみ常駐し、必要がある場合に対応することが生 活援助員要綱に規定されている。

注 8 ) (6)シルバーピアC S のふれあいランチ（企画５０）は、ピア入居者も 対象としているが、現在は地域高齢者のみが参加している。

（2010年 3 月10日原稿受理，2010年 9 月13日採用決定） 